\title{
A novel truncating AIP mutation, p.W279*, in a familial isolated pituitary adenoma (FIPA) kindred
}

\author{
Güven Barış Cansu, ${ }^{1}$ Bengür Taşkıran, ${ }^{1}$ Giampaolo Trivellin,, ${ }^{2}$ \\ Fabio R. Faucz, ${ }^{2}$ Constantine A. Stratakis ${ }^{2}$
}

${ }^{1}$ Division of Endocrinology and Metabolism, Yunus Emre State Hospital, 26190, Eskişehir, Turkey; ${ }^{2}$ Section on Endocrinology and Genetics, Eunice Kennedy Shriver National Institute of Child Health and Human Development (NICHD), National Institutes of Health (NIH), Bethesda, MD, 20892, USA

\begin{abstract}
Familial isolated pituitary adenomas (FIPA) constitute 2-3\% of pituitary tumours. $A I P$ is the most commonly mutated gene in FIPA. We herein report a novel germline mutation of the $A I P$ gene in a family with FIPA. We present two patients, a father and his 12-year-old daughter, diagnosed clinically and using laboratory measures with acromegaly-gigantism. Both underwent transsphenoidal hypophyseal surgery for macroadenomas. We initially detected a novel heterozygous germline $A I P$ mutation, c.836G $>$ A $($ p.W279*), in the father's DNA. We then found the same mutation in his affected daughter. Pituitary adenomas associated with $\boldsymbol{A I P}$ mutations mostly present as FIPA $(68 \%)$ at an early age $(78 \%$ occur at $<30$ years old). They are often growth hormone (GH) - or prolactin - secreting macroadenomas (88\%) that have already extended beyond the sella at the time of diagnosis. Acromegalic cases are resistant to somatostatin analogues and multimodal management is frequently essential to control the disease. Our patients had normalized GH/IGF-1 values soon after surgery, although enough time may not have elapsed to reach final cure. While penetrance of the disease can be as low as $10 \%$ in FIPA, especially children and young patients with somatotropinoma and prolactinoma should be surveyed for inactivating mutations or deletions in AIP. Determining the causative mutations may be of assistance in early diagnosis, treatment success, and genetic counseling.
\end{abstract}

Key words: AIP mutation, Familial isolated pituitary adenoma, Gigantism

\section{INTRODUCTION}

Hypophyseal (pituitary) adenomas are one of the

Address for correspondence:

Güven Barış Cansu, Division of Endocrinology and Metabolism, Yunus Emre State Hospital, Uluönder Mah. Salih Bozok Cad. No. 23, 26190, Tepebaşı, Eskișehir, Turkey;

Tel.: 022221195 95, Fax: 022233520 41,

E-mail: bcansu74@hotmail.com

Received: 15-06-2016, Accepted: 22-06-2016 most common intracranial neoplasms. Most occur sporadically, while $5 \%$ of all cases present as a component of inherited syndromes due to germline mutations in different genes, such as MEN1 (encoding menin), $A I P$ (encoding aryl hydrocarbon receptor interacting protein), PRKARIA (encoding protein kinase cAMPdependent type I regulatory subunit alpha), and $C D$ $K N 1 B$ (encoding cyclin-dependent kinase inhibitor 1B). ${ }^{1,2}$ The first isolated familial pituitary tumors, 
which in most cases were familial acromegaly, were identified in $1999 .{ }^{3}$ Following reports from the same center, familial isolated pituitary adenoma (FIPA) was identified as a separate clinical entity. ${ }^{4}$

FIPA is characterized by pituitary adenomas occurring in two or more family members and absence of genetic and clinical features of multiple endocrine neoplasia type 1 (MEN-1), multiple endocrine neoplasia type 4 (MEN-4), Carney complex, or other multitumour conditions. ${ }^{4}$ FIPA is found in $2-3 \%$ of pituitary adenomas. ${ }^{4}$ AIP, which was first identified as causative of FIPA in 2006, is the most commonly mutated gene. ${ }^{5,6}$ We herein report a novel germline mutation of the AIP gene in a family with FIPA.

\section{CASE REPORT}

A 39-year-old male patient presented to the endocrinology outpatient clinic complaining of multiple skin tags all over his body, especially on the neck and under the armpits. The lesions had progressively increased over several years. He was also suffering from facial and hand edema but denied any change in shoe size. On physical examination, a large number of flesh-colored skin tags measuring $0.2-1.5 \mathrm{~cm}$ in size were detected all over the body and especially all over the neck and under the armpits. Acanthosis nigricans was also evident on the neck and under the armpits. He had a blood pressure of 130/80 $\mathrm{mmHg}$, a regular pulse rate of $82 \mathrm{bpm}$, and coarse facial features. Prog- natism was absent. He was $186 \mathrm{~cm}$ tall and weighed $103 \mathrm{~kg}$. He had a body mass index (BMI) of $29.77 \mathrm{~kg} /$ $\mathrm{m}^{2}$ and abdominal obesity. The liver was palpable 2 $\mathrm{cm}$ below the costal margin. Physical examination of other organ systems revealed no abnormality. Family history of acromegaly and gigantism was absent. He described his 12-year-old daughter as being taller and heavier than her peers. At his next visit, his daughter was also examined. She had grown $4-5 \mathrm{~cm}$ in the last year. She was $178 \mathrm{~cm}$ in height (4.3 SDS) and weighed $81 \mathrm{~kg}$ (5.3 SDS). Her BMI was $25.56 \mathrm{~kg} /$ $\mathrm{m}^{2}$. She was over the $97^{\text {th }}$ percentile for both height and weight. Acanthosis nigricans was evident under the armpits. She was at Tanner stage 4 (telarche stage 4 and pubarche stage 4) and had been menstruating for 6 months. Examination of other organs revealed no abnormality.

Basal GH and IGF-1 levels were measured due to clinical suspicion of acromegaly-gigantism in both family members. They were higher than the agematched reference range. GH was measured during the $75 \mathrm{~g}$ oral glucose tolerance test but was not suppressed below $1 \mathrm{ng} / \mathrm{ml}$. Complete blood count and blood chemistry panel were within normal limits. Other pituitary hormone levels were also normal as shown in Table 1.

The father had a right-sided pituitary mass measuring $13 \times 12 \times 8 \mathrm{~mm}$ in size, which was isointense on T1 and T2 weighted MRI images and showed no

Table 1. Laboratory data of patients

\begin{tabular}{|c|c|c|c|c|}
\hline & \multicolumn{2}{|c|}{ Father } & \multicolumn{2}{|c|}{ Daughter } \\
\hline & Before operation & $\begin{array}{l}\text { After operation } \\
\text { (6th month) }\end{array}$ & Before operation & $\begin{array}{c}\text { After operation } \\
\text { (6th month) }\end{array}$ \\
\hline $\mathrm{GH}(\mathrm{ng} / \mathrm{ml})$ & $9.97(0.05-3.0)$ & $0.284(0.05-3.0)$ & $\mathbf{6 . 2 9}(0.05-17.3)$ & $1.07(0.05-17.3)$ \\
\hline IGF-1 (ng/ml) & $626(109-494)$ & $300(109-494)$ & $1504(183-850)$ & $821(183-850)$ \\
\hline PRL (ng/ml) (3.46-19.4) & 13.5 & 13.3 & 15.9 & 11.2 \\
\hline ACTH (pg/ml) (7.2-63.3) & 41.4 & 27.4 & 20.9 & 59.6 \\
\hline Cortisol $(\mu \mathrm{g} / \mathrm{dl})(3.7-19.4)$ & 14.1 & 18.7 & 20.29 & 24.9 \\
\hline $\mathrm{FSH}(\mu \mathrm{IU} / \mathrm{ml})$ & $3.32(0.95-11.95)$ & 2.85 & $3.9(2.55-16.69)$ & 3.5 \\
\hline $\mathrm{LH}(\mu \mathrm{IU} / \mathrm{ml})$ & $3.9(0.57-12.07)$ & 2.1 & $1.64(1.8-11.78)$ & 2.03 \\
\hline TSH $(\mu \mathrm{IU} / \mathrm{ml})(0.35-4.94)$ & 1.39 & 1.84 & 1.94 & 3.39 \\
\hline Free T4 (ng/dl) (0.7-1.48) & 1.06 & 1.12 & 1.05 & 0.94 \\
\hline Calcitonin (pg/ml) (0-10) & $<2$ & - & $<2$ & - \\
\hline
\end{tabular}


enhancement after intravenous contrast medium administration. Minimal extension into the right cavernous sinus was evident. The optic chiasm was spared and other related structures were normal. His daughter also had a right-sided pituitary mass measuring $12 \times 15 \times 10$ $\mathrm{mm}$ in size, which was hypointense on T1 weighted images and hyperintense on T2 weighted MRI images; it consisted of cystic areas and demonstrated no enhancement after intravenous contrast medium administration. The lesion extended into the right cavernous sinus and circumvented the cavernous segment of the internal carotid artery medially. The optic chiasm and other related structures were intact. Both patients had normal visual field examination.

Histologic examination of the father's mass revealed negative staining for ACTH and PRL, extensive positive staining for $\mathrm{GH}$, and negative staining for $\mathrm{p} 53$. The staining index for Ki-67 was lower than $1 \%$. The histologic examination of the girl's mass revealed a disrupted reticular fibrin network, negative staining for ACTH and PRL, and positive staining for GH and p53. The staining index for Ki-67 was $7 \%$.

Both patients provided written informed consent for genetic analysis and Institutional Review Board approval was obtained. We extracted DNA from whole blood and performed Sanger sequencing of the AIP gene (NM_003977.2) with primers covering the exonic sequences as well as the exon-intron junctions. We initially detected a novel heterozygous germline AIP mutation, c.836G $>$ A (p.W279*), in the father's DNA. We subsequently found the same mutation in the affected daughter (Figure 1).

Removal of the pituitary adenomas of both family members was performed by endoscopic transsphenoidal surgery. Somatostatin analogues were not administered either before or after surgery. GH and IGF-1 levels of both patients returned to normal 3 months after surgery and were within normal limits at the 6th month control visit.

\section{DISCUSSION}

In families with FIPA, one of the most important genetic causes is related to mutations and deletions in the AIP gene. These mutations are often characterized by onset at a young age and GH-and PRL-
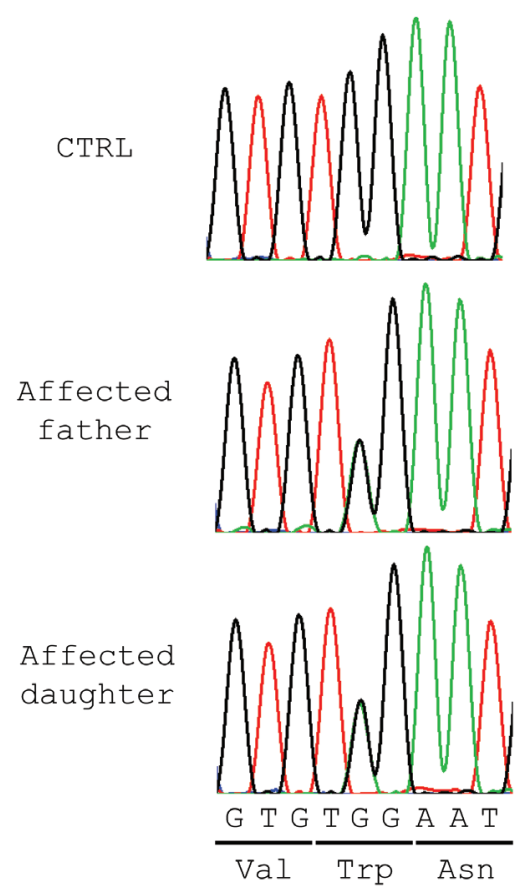

Figure 1. Sequence chromatograms showing the heterozygous AIP mutation detected in both patients. A wild-type sequence from a control subject is shown in the top panel. The $\mathrm{G}>\mathrm{A}$ mutation in the affected patients affects the Tryptophan residue at position 279 by introducing a Stop codon.

secreting pituitary adenomas leading to acromegaly or gigantism. ${ }^{7}$ Until recently, 91 different variants were reported as disease-causing in the AIP gene (HGMD Professional 2016.1 database accessed on 06/2016).

The human AIP gene encodes a $37 \mathrm{kDa}$ protein of 330 amino acids and consists of an N-terminal immunophilin-like domain and a C-terminal tetratricopeptide repeat (TPR) domain similar to other proteins. ${ }^{8}$ Approximately $75 \%$ of all AIP mutations lead to an impaired C-terminal TPR domain and/ or final $\alpha$-7helix. ${ }^{9}$ We herein report the detection of a novel mutation, p.W279*, in the AIP gene. This mutation is located within the third motif of the AIP TPR domain and very likely leads to a dysfunctional truncated protein with impaired ability to interact with chaperones and client proteins. ${ }^{10}$

Pituitary adenomas associated with AIP mutations have several characteristic features: 1) the most frequent clinical presentation is FIPA $(68 \%) ; 2)$ most of 
them are somatotropinomas or prolactinomas; early onset ones can lead to gigantism; 3) $78 \%$ of patients are less than 30 years old; 4 ) most of the adenomas $(88 \%)$ are macroadenomas that have already extended beyond the sella at the time of diagnosis; 5) GH excess is resistant to somatostatin analogues and multimodal management is frequently warranted to control the disease. ${ }^{11}$ The features of our cases represent a typical example of those reported in the literature. Although GH/IGF-1 levels were normalized soon after transsphenoidal surgery, sufficient time may not have elapsed to judge cure.

FIPA may be either homogeneous (affected family members having identical pituitary tumor types) or heterogeneous (affected family members having different pituitary tumor types). ${ }^{4}$ Our case was an example of homogeneous FIPA due to GH-secreting pituitary adenomas in both members.

The penetrance of FIPA varies between 10 to $50 \%{ }^{12}$ Especially children and young patients with somatotropinomas and prolactinomas should be surveyed for inactivating mutations or deletions in AIP. Determining the causative mutations may be of benefit in early diagnosis, treatment success, and genetic counseling.

\section{FUNDING STATEMENT}

This study was supported by the research project Z01-HD008920 (Principal Investigator: Dr. Constantine A. Stratakis) of the Intramural Research Program of the Eunice Kennedy Shriver National Institute of Child Health \& Human Development (NICHD), National Institutes of Health (NIH), Bethesda, MD, USA.

\section{DECLARATION OF INTEREST}

The authors declare that there is no conflict of interest that could be perceived as prejudicing the impartiality of the research reported.

\section{REFERENCES}

1. Lecoq AL, Kamenicky P, Guiochon-Mantel A, Chanson P, 2015 Genetic mutations in sporadic pituitary adenomas--what to screen for? Nat Rev Endocrinol 11: 43-54.

2. Daly AF, Tichomirowa MA, Beckers A, 2009 The epidemiology and genetics of pituitary adenomas. Best Pract Res Clin Endocrinol Metab 23: 543-554.

3. Verloes A, Stevenaert A, Teh BT, Petrossians P, Beckers A, 1999 Familial acromegaly: case report and review of the literature. Pituitary 1: 273-277.

4. Daly AF, Jaffrain-Rea ML, Ciccarelli A, et al, 2006 Clinical characterization of familial isolated pituitary adenomas. J Clin Endocrinol Metab 91: 3316-3323.

5. Vierimaa O, Georgitsi M, Lehtonen R, et al, 2006 Pituitary adenoma predisposition caused by germline mutations in the AIP gene. Science 312: 1228-1230.

6. Daly AF, Vanbellinghen JF, Khoo SK, et al, 2007 Aryl hydrocarbon receptor-interacting protein gene mutations in familial isolated pituitary adenomas: analysis in 73 families. J Clin Endocrinol Metab 92: 1891-1896.

7. Chahal HS, Chapple JP, Frohman LA, Grossman AB, Korbonits M, 2010 Clinical, genetic and molecular characterization of patients with familial isolated pituitary adenomas (FIPA). Trends Endocrinol Metab 21: 419-427.

8. Linnert M, Haupt K, Lin YJ, et al, 2012 NMR assignments of the FKBP-type PPIase domain of the human aryl-hydrocarbon receptor-interacting protein (AIP). Biomol NMR Assign 6: 209-212.

9. Ozfirat Z, Korbonits M, 2010 AIP gene and familial isolated pituitary adenomas. Mol Cell Endocrinol 326: 71-79.

10. Morgan RM, Hernandez-Ramirez LC, Trivellin G, et al, 2012 Structure of the TPR domain of AIP: lack of client protein interaction with the $\mathrm{C}$-terminal alpha-7 helix of the TPR domain of AIP is sufficient for pituitary adenoma predisposition. PLoS One 7: e53339.

11. Daly AF, Beckers A, 2015 Familial isolated pituitary adenomas (FIPA) and mutations in the aryl hydrocarbon receptor interacting protein (AIP) gene. Endocrinol Metab Clin North Am 44: 19-25.

12. Stiles CE, Korbonits M 2000 Familial Isolated Pituitary Adenoma. In: De Groot LJ, Beck-Peccoz P, Chrousos G, Dungan K, Grossman A, Hershman JM, et al, editors. Endotext. South Dartmouth (MA). 